\title{
Genetic Variation and Possible Mechanisms Driving the Evolution of Worldwide Fig mosaic virus Isolates
}

\author{
Jeewan Jyot Walia, Anouk Willemsen, Eminur Elci, Kadriye Caglayan, Bryce W. Falk, and Luis Rubio
}

First author: Department of Plant Pathology, University of California, Davis 95616, and Nebraska Centre for Virology, University of Nebraska, Lincoln 68583; second author: Instituto de Biología Molecular y Celular de Plantas-CSIC-UPV, Valencia, Spain; third and fourth authors: Department of Plant Protection, Agriculture Faculty, Mustafa Kemal University, 31034 Antakya-Hatay, Turkey; fifth author: Department of Plant Pathology, University of California, Davis; and sixth author: Instituto Valenciano de Investigaciones Agrarias, 46113 Moncada, Valencia, Spain.

Accepted for publication 4 August 2013.

\begin{abstract}
Walia, J. J., Willemsen, A., Elci, E., Caglayan, K., Falk, B. W., and Rubio, L. 2014. Genetic variation and possible mechanisms driving the evolution of worldwide Fig mosaic virus isolates. Phytopathology 104:108-114.

Fig mosaic virus (FMV) is a multipartite negative-sense RNA virus infecting fig trees worldwide. FMV is transmitted by vegetative propagation and grafting of plant materials, and by the eriophyid mite Aceria ficus. In this work, the genetic variation and evolutionary mechanisms shaping FMV populations were characterized. Nucleotide sequences from four genomic regions (each within the genomic RNAs 1, 2, 3, and 4) from FMV isolates from different countries were determined and analyzed.

Phylogenetic analysis showed some geographically distant FMV isolates which clustered together, suggesting long-distance migration. The extent of migration was limited, although varied, between countries, such that FMV populations of different countries were genetically differentiated. Analysis using several recombination algorithms suggests that genomes of some FMV isolates originated by reassortment of genomic RNAs from different genetically similar isolates. Comparison between nonsynonymous and synonymous substitutions showed selection acting on some amino acids; however, most evolved neutrally. This and neutrality tests together with the limited gene flow suggest that genetic drift plays an important role in shaping FMV populations.
\end{abstract} FMV genetic variation was low, as is seen for many other plant viruses.
RNA virus populations, including those within an individual virus-infected host or those in different host individuals, are heterogeneous in nature. For RNA viruses, this is often attributed to their large population sizes, short generation times, and high mutation rates from error-prone replication by the viral RNAdependent RNA polymerase ( $\mathrm{RdRp}$ ), which lacks a proofreading activity (9). Additional sources which can give rise to genetic variation include genome recombination and reassortment (39). The genetic diversity and structure of virus populations are limited and shaped by natural selection, genetic drift, and gene flow (37). The effects of these evolutionary mechanisms are also affected by the virus biology (e.g., host type and range, and means and extent of spread), the ecological environment, and population parameters (e.g., population size and history of population bottlenecks). Understanding the factors involved in the genetic diversity and structure of virus populations is fundamental for designing effective strategies for disease control or virus eradication (1).

Like many animal viruses and bacteriophages, some RNA plant viruses have measurably evolving populations $(11,20)$ whereas others evolve more slowly and have genetically stable populations (19). Two key aspects affecting virus evolution are the means of spread and host type. Plant viruses mostly utilize specific vectors for their plant-to-plant transmission (40). Plant-to-plant spread of viruses among herbaceous annual plants may be rapid and the life of the plant host is relatively short. Thus, these viruses are con-

Corresponding author: L. Rubio; E-mail address: lrubio@ivia.es

* The $\boldsymbol{e}$-Xtra logo stands for "electronic extra" and indicates that the online version contains one supplemental figure and one supplemental table.

http://dx.doi.org/10.1094/PHYTO-05-13-0145-R

(c) 2014 The American Phytopathological Society stantly infecting and adapting to new plant hosts. By contrast, the chronic infections in woody perennial plants can last for decades, with or without observable symptoms (44). In addition, most perennial crop plants are vegetatively propagated. If source plants used for propagation are virus infected, this provides opportunity for efficient transfer and maintenance of the chronic infections in the offspring or cuttings. These chronic infections provide ideal settings for the long-term evolution of the viruses within a host plant and, presently, little information is available regarding their evolution.

In this work, we studied Fig mosaic virus (FMV), which affects fig (Ficus carica L.) trees worldwide (12). The fig tree is a perennial, one of the earliest plants domesticated by humans, and is grown throughout the world in temperate to tropical environments (27). FMV is efficiently transmitted by vegetative propagation and grafting but is not seed transmitted. FMV is also specifically transmitted plant to plant by the eriophyid mite Aceria ficus (16). FMV is a hexapartite, negative-strand single-stranded RNA genome virus (24). Each anti-genomic segment is monocistronic. RNA 1 encodes for an RdRp, RNA 2 encodes a putative glycoprotein precursor, RNA 3 encodes a nucleocapsid (NP) protein, RNA 4 encodes a putative movement protein, and RNA 5 and RNA 6 encode proteins of unknown functions $(13,24,25,52)$. The genome organization and the deduced amino acid sequences of FMV-encoded proteins are similar to those of another eriophyid mite-transmitted virus, European mountain ash ringspot associated virus (EMARAV). Based on this, the genus Emaravirus (unassigned family) was proposed which contains EMARAV and tentatively three other species, one of which is FMV $(12,24$, 38,52).

In this study, we estimated the genetic variation and population structure of FMV isolates collected from diverse worldwide locations by analyzing the nucleotide sequences of four regions, one 
each of genomic RNAs 1, 2, 3, and 4. The roles of the evolutionary factors recombination, selection, genetic drift, and gene flow were examined.

\section{MATERIALS AND METHODS}

Virus isolates. Samples were collected from 37 FMV isolates from California, Turkey, and Israel (Fig. 1). In all, 21 FMV isolates were from California, including 10 collected from different commercial orchards and 11 obtained from the United States Department of Agriculture (USDA) National Clonal Germplasm Repository, University of California (UC), Davis. The repository currently has 190 fig accessions from different parts of the world (47), and all of these plants show visible symptoms of the fig mosaic disease (52). Ten isolates were collected from different regions of Turkey and six isolates were obtained from trees imported from Israel by the California Department of Food and Agriculture, Riverside. Nucleotide sequences from 16 additional

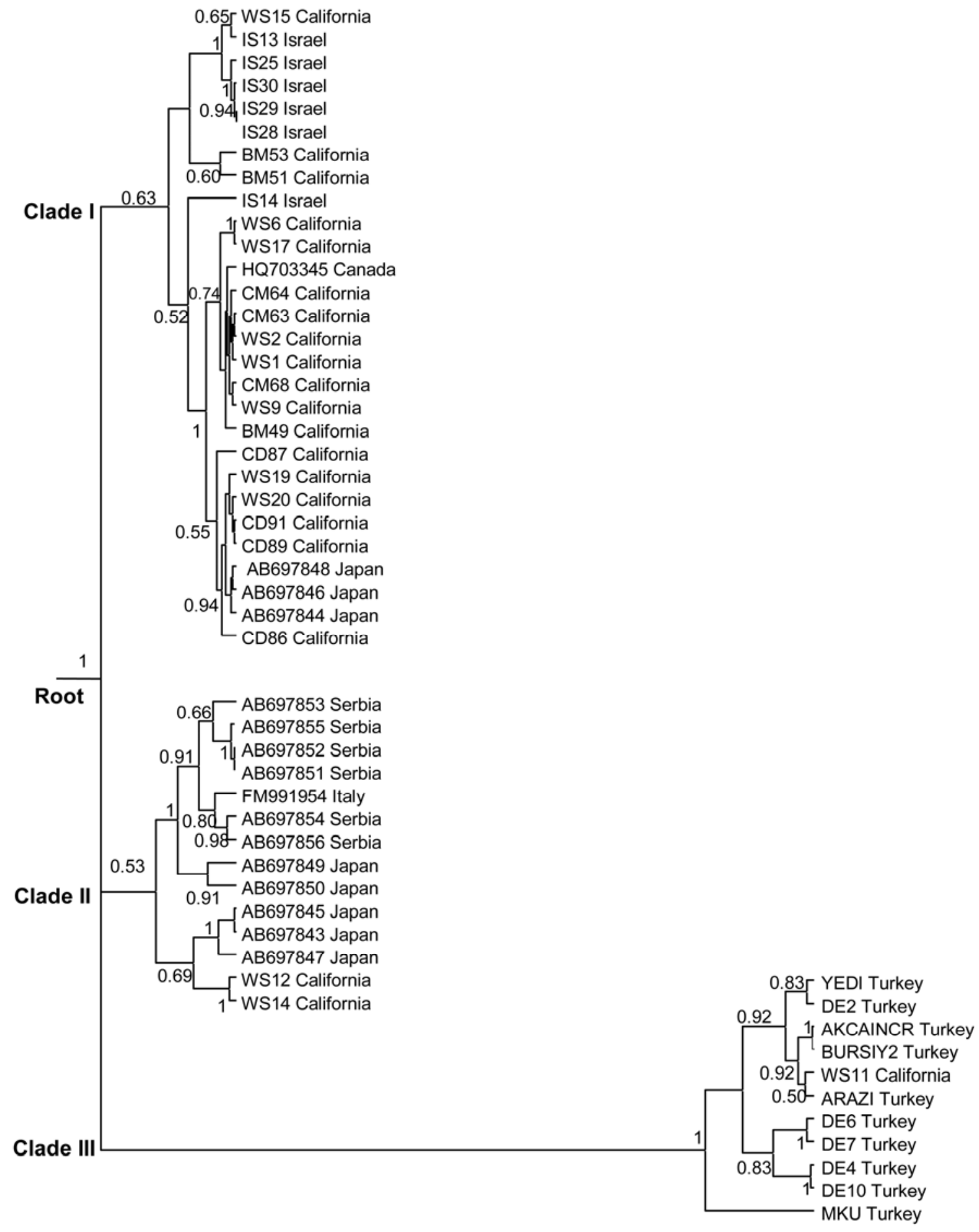

0.05

Fig. 1. Bayesian phylogenetic tree of the nucleocapsid gene of Fig mosaic virus isolates from California, Canada, Italy, Serbia, Turkey, Israel, and Japan. Node significance was indicated by posterior probability values $(\geq 0.50)$. California isolates obtained from a germplasm collection are named as WS followed by a number, whereas the other Californian isolates are from commercial fields and given a B or C. Sequences from GenBank are indicated by their respective numbers. 
isolates (1 from Canada, 1 from Italy, 8 from Japan, and 6 from Serbia) were retrieved from GenBank (accession numbers in Figure 1).

Genotyping. Total RNA was extracted from symptomatic fig leaves by using the Qiagen RNeasy Plant mini kit (Qiagen Sciences, MD). Oligonucleotide primers were designed for the genomic RNAs 1, 2, 3, and 4 (Table 1). A one-step reverse-transcription polymerase chain reaction (RT-PCR) was performed at $47^{\circ} \mathrm{C}$ for $30 \mathrm{~min}$ (reverse transcription); then, 35 cycles of $94^{\circ} \mathrm{C}$ for $30 \mathrm{~s}, 51^{\circ} \mathrm{C}$ for $45 \mathrm{~s}$, and $72^{\circ} \mathrm{C}$ for $1 \mathrm{~min}$; and a final extension for $7 \mathrm{~min}$ at $72^{\circ} \mathrm{C}$. The amplified products were analyzed by agarose gel electrophoresis and stained with SYBR Gold (Invitrogen, Molecular Probes Inc., Eugene, OR) as per the manufacturer's instructions. Bands were cut from the gels and DNA was extracted by using the Minelute Gel extraction kit (Qiagen Sciences). The purified RT-PCR products were directly sequenced with the respective primers, using the ABI 3730 Capillary Electrophoresis Genetic Analyzer at the UC DNA Sequencing facility, UC Davis. No ambiguous sites were found, indicating a within-isolate homogeneous population and absence of mixed infections. Nucleotide sequences were deposited in GenBank under accession numbers $\mathrm{KC} 182474$ to $\mathrm{KC} 182510$ and KC295716 to KC295790.

Nucleotide sequence analysis. Multiple sequence alignments were performed with the algorithm CLUSTAL W (29) implemented in the program MEGA 5.05 (49). The nucleotide substitution model which best fits the sequences and the nucleotide divergence to correct superimposed substitutions (42) was estimated with MEGA 5.05. The best nucleotide substitution model (that with the lowest Akaike Information Criterion value) was the general time reversible (GTR) with nonuniformity of evolutionary rates among sites. It is modeled by using a discrete $\gamma$ distribution $(+\mathrm{G})$ with five rate categories and by assuming that a certain fraction of sites are evolutionarily invariable $(+\mathrm{I})$. The estimate of $\gamma$ shape parameter was 0.29 and the estimated fraction of invariant sites was 0.56 .

The aligned sequences of the $N P$ gene of FMV RNA 3 were used to infer a Bayesian phylogenetic tree (node significance was estimated with posterior probabilities) by using the program BEAST version 1.7.4 (10) using the estimated GTR $+\Gamma_{4}+$ I substitution model. The MCMC was run for $10^{8}$ samplings every 1,000 trees to ensure convergence of all parameters. The BEAST output was analyzed using TRACER, version 1.5 (tree.bio.ed.ac. $\mathrm{uk} /$ software/tracer) with satisfaction of the effective sample sizes (posterior $=324.747$, likelihood $=11,795.484)$. The sample of

TABLE 1. Primers used to reverse-transcription polymerase chain reaction (RT-PCR) amplify regions of the four Fig mosaic virus (FMV) genomic RNAs

\begin{tabular}{lccc}
\hline Primer sequence $^{\mathrm{a}}$ & $\begin{array}{c}\text { Genomic } \\
\text { region }^{\mathrm{b}}\end{array}$ & $\begin{array}{c}\text { Amplified } \\
\text { region (nt) }^{\mathrm{c}}\end{array}$ & $\begin{array}{c}\text { Size } \\
\text { (nt) }^{\mathrm{d}}\end{array}$ \\
\hline $\begin{array}{l}\text { GTTATGGCTATATATTCTGATTATTC } \\
\text { TCAAACTTGTATGGTGTGTAATA }\end{array}$ & $\begin{array}{c}\text { RNA 1 } \\
\text { (RdRp) }\end{array}$ & $2,170-2,537$ & 367 \\
$\begin{array}{l}\text { AGATGTGGGAAAATCATATGCT } \\
\text { AGACCAACTTGCAGGCTTTT }\end{array}$ & $\begin{array}{c}\text { RNA 2 } \\
\text { (GP) }\end{array}$ & $1,535-2,107$ & 572 \\
$\begin{array}{l}\text { GTCATGTTGATACATGTGCTGC } \\
\text { CACACTTACACATCTTACATCATCT }\end{array}$ & $\begin{array}{c}\text { RNA 3 } \\
\text { (NP) }\end{array}$ & $347-1,220$ & 873 \\
$\begin{array}{l}\text { GATCTTGTTGGAAACACAATA } \\
\text { GCTTTGGCAGATTCTATT }\end{array}$ & $\begin{array}{c}\text { RNA 4 } \\
\text { (MP) }\end{array}$ & $490-1,073$ & 583 \\
\hline
\end{tabular}

a Oligonucleotide primers used. The upper sequence corresponds to the forward primer complementary to the negative strand and the lower to the reverse primer complementary to the positive strand.

${ }^{\mathrm{b}}$ Genomic regions where the primers are located: RNA-dependent RNA polymerase (RdRp) encoded in RNA 1, glycoprotein (GP) encoded in RNA 2, nucleocapsid (NP) protein encoded in RNA 3, and a protein of unknown function encoded in RNA 4.

c Nucleotide (nt) positions of the primers in the respective FMV genomic RNAs are indicated.

${ }^{\mathrm{d}}$ Expected size (nt) of the RT-PCR products. the trees was summarized into the maximum clade credibility phylogeny using TREEANNOTATOR, version 1.7.4 (beast.bio. ed.ac.uk/TreeAnnotator), discarding the first $10 \%$ of sampled trees as burn-in. Nucleotide diversities (mean nucleotide distances between sequence pairs) of the FMV NP gene within and between geographic populations (standard errors were calculated with 1,000 bootstrap replicates) were estimated with MEGA 5.05. The program DNASP 5.0 (30) was used to estimate genetic differentiation between populations with three permutation-based statistical tests $\left(\mathrm{Ks}^{*}, \mathrm{Z}^{*}\right.$, and $\left.\mathrm{S}_{\mathrm{nn}}\right)(22,23)$ as well as the level of gene flow with the statistic $\mathrm{F}_{\mathrm{st}}$, which has values between 0 and 1 for complete and absence of gene flow (53).

The program RDP3, which contains the recombination-detecting algorithms GENECONV, BOOTSCAN, MAXCHI, SISCAN, 3SEQ, LARD, and RDP (33), was used to search for possible recombination or reassortment events by analysis of the concatenated FMV genomic regions located in RNAs 1, 2, 3, and 4, respectively.

The degree of selective constraints at the amino acid level was estimated with MEGA 5.05 by analyzing separately the rate of nonsynonymous $(\mathrm{dN})$ and synonymous $(\mathrm{dS})$ substitutions with the Pamilo-Bianchi-Li method (41). The difference between $\mathrm{dN}$ and $\mathrm{dS}$ provides information on the sign and intensity of selection. Selection across the genomic coding regions was studied by estimation of the rates of $\mathrm{dN}$ and $\mathrm{dS}$ at each codon using the fixed effects likelihood method (28) implemented in the Datamonkey Server (http://www.datamonkey.org/). The program DNASP 5.10 (30) was used to evaluate the importance of natural selection to shape an FMV population by testing the mutation neutrality hypothesis with several statistics: Tajima's D, based on the differences between the number of segregating sites and the average number of nucleotide differences (48); Fu and Li's D test, based on the differences between the number of singletons (mutations appearing only once among the sequences) and the total number of mutations (18); and Fu and Li's F test, based on the differences between the number of singletons and the average number of nucleotide differences between every pair of sequences (18). Significant deviation from the neutral hypothesis would indicate selection but this can also be produced by a rapid growth of the viral population after a bottleneck event.

\section{RESULTS AND DISCUSSION}

Genetic structure and variation of FMV. The genetic structure and the degree of genetic variation must be considered for designing and evaluating strategies of disease control (1). For example, plant breeding to obtain resistant cultivars should be assessed with different viral isolates covering the virus genetic spectrum because resistance would depend on specific virus-host interactions (17). To estimate the genetic structure of FMV, the phylogenetic relationships of the $N P$ gene of 53 FMV isolates from different countries were inferred. This analysis showed three well-resolved main clades (Fig. 1). Clade I was composed of all isolates collected in field in California, 10 of 13 isolates collected from the California germplasm collection, the Canadian isolate, all isolates from Israel, and 3 isolates from Japan. Clade II contained two isolates from the California germplasm and isolates from Italy, Serbia, and Japan. Finally, clade III was composed of all isolates from Turkey and one from the California germplasm collection.

The close genetic relationships between some geographically distant isolates suggest long-distance migration, probably due to the international traffic of propagative fig material. This has been also observed for other plant viruses $(34,45)$. The phylogeny topology showed that at least three independent introductions of divergent FMV isolates have occurred in California, most likely via importation of germplasm material. However, only one of the three introductions (clade I) has spread in the field. Nucleotide 
variation was low, with the highest nucleotide distance between two isolates being 0.057 and a mean nucleotide distance of $0.030 \pm 0.005$. This is in the range seen for an equivalent genomic region of EMARAV (26) and most plant viruses (19). The mean nucleotide distance for several viruses infecting woody perennial and annual crops $(8,15,34,45,46,51)$ is shown in Supplemental Figure 1. There seems to be no correlation between the host type and the nucleotide variation. For example, the mean nucleotide distance was low for two members of the family Closteroviridae, Citrus tristeza virus (CTV) and Cucurbit yellow stunting disorder virus, infecting woody and herbaceous plants, respectively, whereas it was much higher for two members of the family Secoviridae, Grapevine fan leaf virus and Broad bean wilt virus 2 , infecting woody and herbaceous plants, respectively.

Genetic diversity and gene flow of geographically distinct FMV populations. The great ability of RNA viruses to evolve rapidly with respect to cellular organisms implies that epidemiological and evolutionary processes occur on a similar temporal scale and can interact with each other (21). Comparison between virus populations from different geographic areas can provide relevant information to understand the emergence, epidemiology, short- and long-distance movement, and gene flow of viruses which can be implemented in disease control strategies based on limiting virus dispersion.

The genetic diversity of the FMV NP gene for populations from six geographic areas was estimated (Table 2). Our analysis showed that the nucleotide diversity of FMV in each area was very low ( 0.009 for Israel, $\approx 0.015$ for California and Serbia, and $\approx 0.030$ for Turkey and Japan) whereas those between most areas were a little higher. It is difficult to compare the nucleotide diversity with other plant viruses occupying the same geographic area because these studies are scarce and differ in sampling size, location, and date. In California, nucleotide diversity of Cucumber mosaic virus, CTV, and Citrus psorosis virus have been estimated as $\approx 0.030(31,34,46)$, which is also low in comparison with bacteriophages, animal viruses, and some plant viruses $(14,20)$.

Genetic differentiation was evaluated with the statistical tests $\mathrm{Ks}^{*}, \mathrm{Z}^{*}$, and $\mathrm{S}_{\mathrm{nn}}$, and the extent of genetic differentiation and, therefore, gene flow was estimated with the coefficient $F_{\text {st }}$. When samples collected from the USDA Germplasm collection (located at UC Davis) were compared with the isolates collected from commercial fields in California, the $\mathrm{F}_{\text {st }}$ value was equal to -0.021 and the three statistical tests were nonsignificant. This indicates that the isolates from the Germplasm collection and from commercial fields are closely related and, from a genetic view, can be considered as the same population. The results of these analyses when compared for FMV isolates from different geographic regions are shown in Table 3. In all cases, the tests $\mathrm{Ks}^{*}$, $Z^{*}$, and $S_{n n}$ gave significant values suggesting strong genetic differentiation. $\mathrm{F}_{\mathrm{st}}$ values were $>0.600$ between California, Serbia, and Israel FMV isolates, suggesting very infrequent gene flow between these populations. They were $\approx 0.400$ between Turkey and Serbia or Israel FMV isolates, and between Japan and Serbia or Israel FMV isolates, suggesting moderate gene flow. Finally, $\mathrm{F}_{\mathrm{st}}$ values $<0.120$ were estimated between California and Japan
FMV isolates and between them and Turkey FMV isolates, which suggests a certain gene flow. These results agree with those obtained in our phylogenetic analysis (Fig. 1).

Reassortment or recombination for FMV. Recombination and reassortment (pseudorecombination) events were analyzed because these can promote genome diversity and adaptability or offset fitness decrease by accumulation of deleterious mutations in bottleneck events $(3,39)$. The analysis of the concatenated four genomic regions located in the genomic segments $1,2,3$, and 4, respectively, suggested that some FMV isolates could have arisen via genome segment reassortment between co-infecting different FMV isolates (Fig. 2). The Turkish FMV isolates ARAZI and YEDI seem to have acquired RNA 2 from an unknown FMV isolate whereas the other three segments could have originated from an ancestor of isolate BM49. The Californian isolates WS19, WS20, CD86, CD87, CD89, and CD91 most likely originated from four different reassortment events between the ancestors of FMV isolates IS28 and CM68. Thus, WS19 and WS20 evolved from IS28-like RNAs 1 and 4 and CM68-like RNAs 2 and 3; CD86 from IS28-like RNAs 1 and 2 and CM68-like RNAs 3 and 4; CD87 from an IS28-like RNA 1 and CM68-like RNAs 2, 3, and 4; and CD89 and CD91 from IS28-like RNAs 1, 2, and 4 and a CM68-like RNA 3. Finally, FMV isolates CM63 and CM68 seem to have acquired RNA 1 from a WS11 ancestor and the other three RNAs from a CM64 ancestor, whereas isolate WS1 likely acquired RNA 1 from a CAN01 ancestor and the other three RNAs from an unknown FMV isolate. Reassortment has been found in other negative-sense plant RNA viruses (e.g., Tomato spotted wilt virus) (50) and other multipartite plant viruses $(2,31,36)$. By contrast, no recombination events were found within any genomic segment analyzed here; however, the genome regions analyzed here are relatively small and, thus, we cannot rule out that recombination could have happened in the nonanalyzed genomic regions. However, recombination in negativesense RNA viruses is reported to be rare (4), in contrast to positive-sense RNA viruses $(5,35)$ or DNA viruses $(7)$.

Genetic variation and selective pressure for different genomic regions of FMV. Natural selection and genetic drift are two main evolutionary mechanisms limiting genetic variation of virus populations (37). The genetic variation for the four genomic regions of FMV was determined (Table 4). The coding regions of RNAs 3 and 4 had relatively low genetic variation (nucleotide diversity $\approx 0.020$ and proportion of polymorphic sites $\approx 0.090$ ) whereas the

TABLE 3. Genetic differentiation and gene flow of the nucleocapsid gene between Fig mosaic virus (FMV) populations from different geographic locations $^{\text {a }}$

\begin{tabular}{lccccc}
\hline Location & Isolates & California & Serbia & Turkey & Israel \\
\hline California & 21 & $\ldots$ & $\ldots$ & $\ldots$ & $\ldots$ \\
Serbia & 6 & $0.637^{*}$ & $\ldots$ & $\ldots$ & $\ldots$ \\
Turkey & 10 & $0.118^{*}$ & $0.465^{*}$ & $\ldots$ & $\ldots$ \\
Israel & 6 & $0.625^{*}$ & $0.706^{*}$ & $0.403^{*}$ & $\ldots$ \\
Japan & 8 & $0.114^{*}$ & $0.400^{*}$ & $0.097^{*}$ & $0.451^{*}$
\end{tabular}

a Values correspond to $\mathrm{F}_{\mathrm{st}}$ statistic which estimates gene flow between FMV populations. An asterisk (*) means that the genetic differentiation was statistically significant according to the three tests: $\mathrm{K}_{\mathrm{st}}{ }^{*}, \mathrm{Z}^{*}$, and $\mathrm{S}_{\mathrm{nn}}$.

TABLE 2. Nucleotide diversity of the nucleocapsid gene within and between Fig mosaic virus (FMV) populations from different geographic areas ${ }^{\mathrm{a}}$

\begin{tabular}{|c|c|c|c|c|c|c|}
\hline Areas & Isolates & California & Serbia & Turkey & Israel & Japan \\
\hline California & 21 & $0.013 \pm 0.003$ & $\ldots$ & $\ldots$ & $\ldots$ & $\ldots$ \\
\hline Serbia & 6 & $0.040 \pm 0.008$ & $0.014 \pm 0.003$ & $\ldots$ & $\ldots$ & $\ldots$ \\
\hline Turkey & 10 & $0.024 \pm 0.004$ & $0.043 \pm 0.007$ & $0.029 \pm 0.007$ & $\ldots$ & $\ldots$ \\
\hline Israel & 6 & $0.029 \pm 0.007$ & $0.042 \pm 0.009$ & $0.032 \pm 0.006$ & $0.009 \pm 0.002$ & $\ldots$ \\
\hline Japan & 8 & $0.025 \pm 0.004$ & $0.040 \pm 0.006$ & $0.043 \pm 0.007$ & $0.038 \pm 0.008$ & $0.032 \pm 0.006$ \\
\hline
\end{tabular}

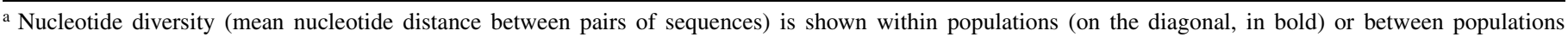
(below the diagonal). Standard errors are indicated. 
regions of RNAs 1 and 2 showed a nucleotide diversity approximately five times higher $(\approx 0.100)$ and approximately three times more polymorphic sites $(\approx 0.265)$.

It is assumed that the potential for mutation rates is the same along the genomic RNAs and that the differences seen in genetic variation then must result from different selective pressures exerted in the RNA coding regions. To evaluate the sign and intensity of selection at both nucleotide and amino acid levels, the $\mathrm{dS}$ and $\mathrm{dN}$ nucleotide substitutions were computed separately. The genomic regions analyzed from RNAs 3 and 4 had dN values much lower ( 0.003 and 0.002 , respectively) than those for RNA 1 (0.013) and RNA 2 (0.026), suggesting a very strong negative selection probably due to functional or structural constrictions of the encoded proteins. RNAs 3 and 4 showed lower dS values $(\approx 0.063)$ than those for RNA $2(0.150)$ and RNA $3(0.262)$, also suggesting negative selection at the nucleotide level. Selection at the nucleotide level could occur by thermodynamic stability of RNA (secondary structure), codon usage bias for translation efficiency, activation of gene silencing, and RNA-RNA or RNAprotein interactions (6).
Statistical analysis of the ratio of nonsynonymous and synonymous changes for individual codons showed that a total of 90 of 1,905 sites in the four genomic regions were under negative selection (Table 4; Supplemental Table 1). These sites could be involved in functional properties or perhaps be critical structural domains. In RNA 2, four sites were identified to be under positive selection, which could be the result of an adaptation of FMV to an environment change. This has been described for other plant viruses (e.g., some isolates of Tomato spotted wilt virus had a positively selected amino acid change which correlated with the ability for these isolates to break resistance conferred by the gene $S w-5$ in tomato) (32). The sites under selection identified in this work can serve as a guide for functional studies based on directed mutagenesis and reverse genetics.

To assess the role of natural selection at the population level, three different neutrality tests were performed. They gave negative values for the four FMV genomic regions, although they did not show significant deviation from neutrality, suggesting that genetic drift would have an important role in shaping the observed FMV populations. This is in accordance with the codon
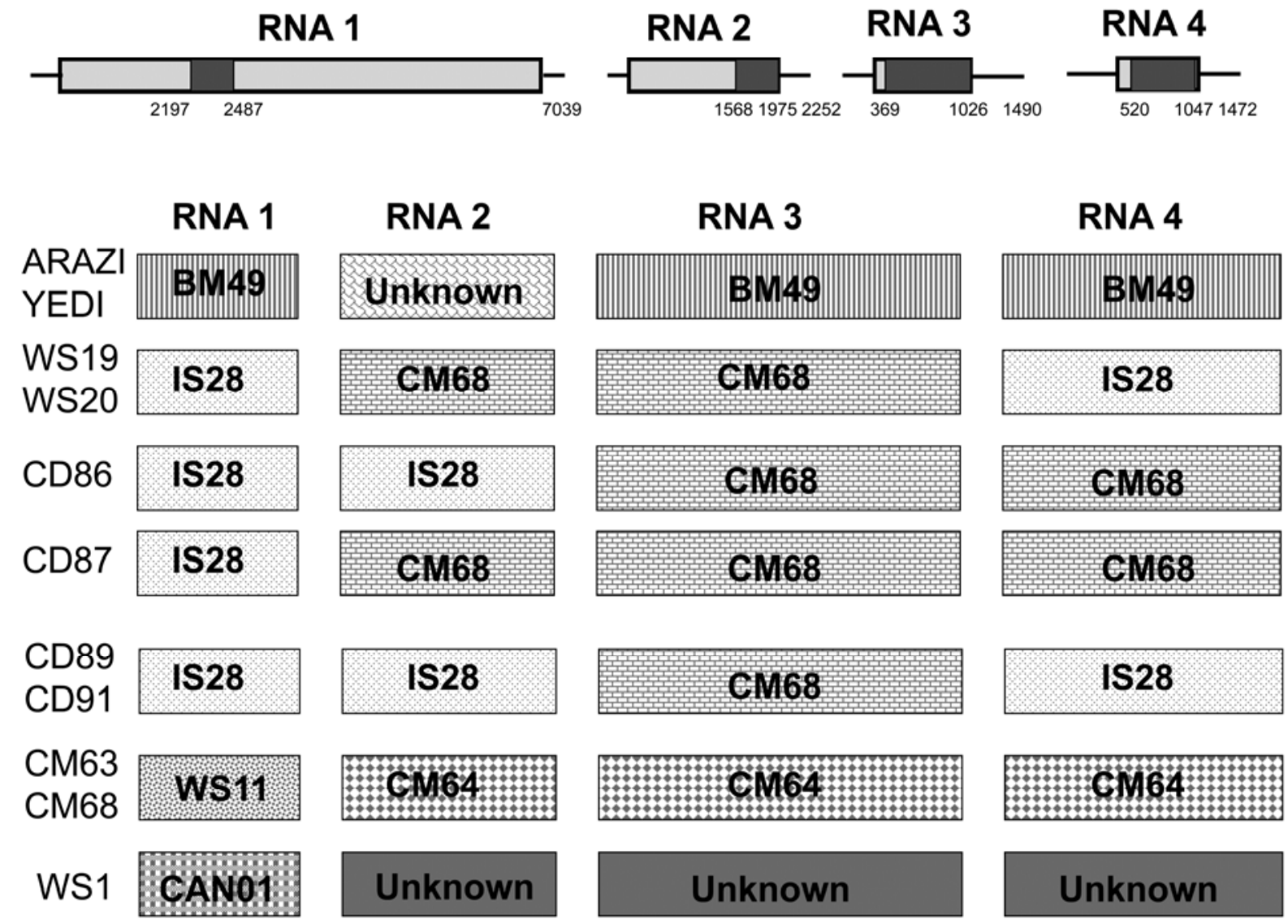

Fig. 2. Schematic representation of the recombination analysis of concatenated Fig mosaic virus (FMV) sequences RNA $1+$ RNA $2+$ RNA 3 + RNA 4 . Possible parental sequences are indicated in the boxes with different patterns. FMV isolate names are given at left.

TABLE 4. Population genetic parameters and neutrality tests calculated for the four Fig mosaic virus (FMV) genomic regions ${ }^{\mathrm{a}}$

\begin{tabular}{|c|c|c|c|c|c|c|c|c|c|c|c|}
\hline Genomic region & $n$ & $\mathrm{~S}$ & $\pi$ & $\mathrm{dS}$ & $\mathrm{dN}$ & $\mathrm{dN} / \mathrm{dS}$ & $\mathrm{Ne}$ & Po & $\begin{array}{c}\text { Tajima's } \\
\text { D }\end{array}$ & $\begin{array}{l}\text { Fu and } \\
\text { Li's D }\end{array}$ & $\begin{array}{c}\text { Fu and } \\
\text { Li's F }\end{array}$ \\
\hline RNA 1 & 291 & 0.261 & $0.111 \pm 0.030$ & $0.262 \pm 0.054$ & $0.013 \pm 0.006$ & 0.050 & 19 & 0 & -0.135 & -0.206 & -0.216 \\
\hline RNA 2 & 408 & 0.270 & $0.099 \pm 0.017$ & $0.150 \pm 0.021$ & $0.026 \pm 0.006$ & 0.173 & 38 & 4 & -0.836 & -0759 & -0.927 \\
\hline RNA 4 & 528 & 0.089 & $0.022 \pm 0.005$ & $0.062 \pm 0.013$ & $0.002 \pm 0.001$ & 0.032 & 20 & 0 & -0.836 & -1.353 & -1.397 \\
\hline
\end{tabular}

${ }^{a}$ Abbreviations: $n=$ number of sites, $\mathrm{S}=$ number of segregating (polymorphic) sites, $\pi=$ nucleotide diversity (mean nucleotide differences per site between sequence pairs), $\mathrm{dS}=$ frequency of synonymous substitution per site, $\mathrm{dN}=$ frequency of nonsynonymous substitution per site, $\mathrm{Ne}=$ number of negatively selected codons, and Po $=$ number of positively selected codons. 
selection analyses, which showed that $95.1 \%$ of the sites were under neutral evolution. This has also been observed in some plant virus populations (8) whereas, in others cases, negative selection seems have played a major role (43).

\section{ACKNOWLEDGMENTS}

This research was supported, in part, by the California Fig Advisory Board and the UC. J. Jyot Walia was supported in part by a Guru Gobind Singh Fellowship (UC Santa Cruz). We thank Dr. Inmaculada Ferriol for valuable suggestions on this manuscript.

\section{LITERATURE CITED}

1. Acosta-Leal, R., Duffy S., Xiong, Z., Hammond, R., and Elena, S. F. 2011. Advances in plant virus evolution: Translating evolutionary insights into better disease management. Phytopathology 101:1136-1148.

2. Brown J., Idris, A., Alteri, C., and Stenger, D. C. 2002. Emergence of a new cucurbit-infecting begomovirus species capable of forming viable reassortants with related viruses in the Squash leaf curl virus cluster. Phytopathology 92:734-742.

3. Chao, L. 1990. Fitness of RNA virus decreased by Muller's ratchet. Nature 348:454-455.

4. Chare, E. R., Gould, E. A., and Holmes, E. C. 2003. Phylogenetic analysis reveals a low rate of homologous recombination in negative-sense RNA viruses. J. Gen. Virol. 84:2691-2703.

5. Chare, E. R., and Holmes, E. C. 2006. A phylogenetic survey of recombination frequency in plant RNA viruses. Arch. Virol. 151 5:933946.

6. Cuevas, J. M., Domingo-Calap, P., and Sanjuán, R. 2012. The fitness effects of synonymous mutations in DNA and RNA viruses. Mol. Biol. Evol. 29:17-20.

7. Davino, S., Miozzi, L., Panno, S., Rubio, L., Davino, M., and Accotto, G. P. 2012. Recombination profiles between Tomato yellow leaf curl virus and Tomato yellow leaf curl Sardinia virus in laboratory and field conditions: Evolutionary and taxonomic implications. J. Gen. Virol. 93: 2712-2717.

8. Davino, S., Panno, S., Rangel, E. A., Davino, M., Bellardi, M. G., and Rubio, L. 2012. Population genetics of Cucumber mosaic virus infecting medicinal, aromatic and ornamental plants from northern Italy. Arch. Virol. 157:739-739.

9. Domingo, E., and Holland, J. 1997. RNA virus mutations and fitness for survival. Annu. Rev. Microbiol. 51:151-178.

10. Drummond, A., and Rambaut, A. 2007. BEAST: Bayesian evolutionary analysis by sampling trees. BMC Evol. Biol. 7:214.

11. Drummond, A. J., Pybus, O. G., Rambaut, A., Forsberg, R., and Rodrigo, A. G. 2003. Measurably evolving populations. Trends Ecol. Evol. 18:481488.

12. Elbeaino, T., Digiaro, M., Alabdullah, A., De Stradis, A., Minafra, A., Mielke, N., Castellano, M. A., and Martelli, G. P. 2009. A multipartite single-stranded negative-sense RNA virus is the putative agent of fig mosaic disease. J. Gen. Virol. 90:1281-1288.

13. Elbeaino, T., Digiaro, M., and Martelli, G. P. 2009. Complete nucleotide sequence of four RNA segments of Fig mosaic virus. Arch. Virol. 154:1719-1727.

14. Fargette, D., Pinel, A., Rakotomalala, M., Sangu, E., Traoré, O., Sérémé, D., Sorho, F., Issaka, S., Hébrard, E., and Séré, Y. 2008. Rice yellow mottle virus, an RNA plant virus, evolves as rapidly as most RNA animal viruses. J. Virol. 82:3584-3589.

15. Ferrer, R. M., Ferriol, I., Moreno, P., Guerri, J., and Rubio, L. 2011. Genetic variation and evolutionary analysis of Broad bean wilt virus 2. Arch. Virol. 156:1445-1450.

16. Flock, R., and Wallace, J. 1955. Transmission of fig mosaic by the eriophyid mite Aceria ficus. Phytopathology 45:52-54.

17. Flor, H. H. 1971. Current status of the gene-for-gene concept. Annu. Rev. Phytopathol. 9:275-296.

18. Fu, Y. X., and Li, W. H. 1993. Maximum likelihood estimation of population parameters. Genetics 134:1261-1270.

19. García-Arenal, F., Fraile, A., and Malpica, J. M. 2001. Variability and genetic structure of plant virus populations. Annu. Rev. Phytopathol. $39: 157-186$.

20. Gibbs, A. J., Fargette, D., García-Arenal, F., and Gibbs, M. J. 2010. Timethe emerging dimension of plant virus studies. J. Gen. Virol. 91:13-22.

21. Grenfell, B. T., Pybus, O. G., Gog. J. R., Wood, J. L. N., Daly, J. M., Mumford, J. A., and Holmes, E. C. 2004. Unifying the epidemiological and evolutionary dynamics of pathogens. Science 303:327-332.

22. Hudson, R. R. 2000. A new statistic for detecting genetic differentiation. Genetics 155:2011-2014.
23. Hudson, R. R., Boos, D. D., and Kaplan, N. L. 1992. A statistical test for detecting geographic subdivision. Mol. Biol. Evol. 9:138-151.

24. Ishikawa, K., Maejima, K., Komatsu, K., Kitazawa, Y., Hashimoto, M., Takata, D., Yamaji Y., and Namba, S. 2012. Identification and characterization of two novel genomic RNA segments of Fig mosaic virus, RNA5 and RNA6. J. Gen. Virol. 93:1612-1619.

25. Ishikawa, K., Maejima, K., Komatsu, K., Netsu, O., Keima, T., Shiraishi, T., Okano, Y., Hashimoto, M., Yamaji, Y., and Namba, S. 2013. Fig mosaic emaravirus p4 protein is involved in cell-to-cell movement. J. Gen. Virol. 94:682-686.

26. Kallinen, A., Lindberg, I., Tugume, A., and Valkonen, J. 2009. Detection, distribution, and genetic variability of European mountain ash ringspotassociated virus. Phytopathology 99:344-352.

27. Kislev, M. E., Hartmann, A., and Bar-Yosef, O. 2006. Early domesticated fig in the Jordan Valley. Science 312:1372-1374.

28. Kosakovsky Pond, S. L., and Frost, S. D. W. 2005. Datamonkey: Rapid detection of selective pressure on individual sites of codon alignments. Bioinformatics 21:2531-2533.

29. Larkin, M. A., Blackshields, G., Brown, N. P., Chenna, R., McGettigan, P. A., McWilliam, H., Valentin, F., Wallace, I. M., Wilm, A., and López, R. 2007. Clustal $\mathrm{W}$ and Clustal $\mathrm{X}$ version 2.0. Bioinformatics 23: 2947-2948.

30. Librado, P., and Rozas, J. 2009. DnaSP v5: A software for comprehensive analysis of DNA polymorphism data. Bioinformatics 25:1451-1452.

31. Lin, H. X., Rubio, L., Smythe, A. B., and Falk, B. W. 2004. Molecular population genetics of Cucumber mosaic virus in California: Evidence for founder effects and reassortment. J. Virol. 78:6666.

32. López, C., Aramburu, J., Galipienso, L., Soler, S., Nuez, F., and Rubio, L. 2011. Evolutionary analysis of tomato $S w-5$ resistance-breaking isolates of Tomato spotted wilt virus. J. Gen. Virol. 92:210-215.

33. Martin, D. P., Lemey, P., Lott, M., Moulton, V., Posada, D., and Lefeuvre, P. 2010. RDP3: A flexible and fast computer program for analyzing recombination. Bioinformatics 26:2462-2463.

34. Martín, S., García, M. L., Troisi, A., Rubio, L., Legarreta, G., Grau, O., Alioto, D., Moreno, P., and Guerri, J. 2006. Genetic variation of populations of Citrus psorosis virus. J. Gen. Virol. 87:3097-3102.

35. Martín, S., Sambade, A., Rubio, L., Vives, M. C., Moya, P., Guerri, J., Elena, S. F., and Moreno, P. 2009. Contribution of recombination and selection to molecular evolution of Citrus tristeza virus. J. Gen. Virol. 90:1527-1538.

36. Miranda, G. J., Azzam, O., and Shirako, Y. 2000. Comparison of nucleotide sequences between northern and southern Philippine isolates of rice grassy stunt virus indicates occurrence of natural genetic reassortment. Virology 266:26-32.

37. Moya, A., Holmes, E. C., and Gonzalez-Candelas, F. 2004. The population genetics and evolutionary epidemiology of RNA viruses. Nat. Rev. Microbiol. 2:279-288.

38. Muhlbach, H.-P., and Mielke-Ehret, N. 2011. Genus Emaravirus. Pages 767-769 in: Virus Taxonomy-Ninth Rep. Int. Committee Taxonomy Viruses. A. M. Q. King, M. J. Adams, E. B. Carstens, and E. J. Lefkowitz, eds. Elsevier Academic Press.

39. Nagy, P. D. 2008. Recombination in plant RNA viruses. Pages 133-164 in: Plant Virus Evolution. Springer-Verlag, Berlin.

40. Ng, J. C. K., and Falk, B. W. 2006. Virus-vector interactions mediating nonpersistent and semipersistent transmission of plant viruses. Annu. Rev. Phytopathol. 44:183-212.

41. Pamilo, P., and Bianchi, N. O. 1993. Evolution of the Zfx and Zfy genes: Rates and interdependence between the genes. Mol. Biol. Evol. 10:271281.

42. Posada, D., and Crandall, K. A. 1998. Modeltest: Testing the model of DNA substitution. Bioinformatics 14:817-818.

43. Rangel, E., Alfaro-Fernández, A., Font-San-Ambrosio, M., Luis-Arteaga, M., and Rubio, L. 2011. Genetic variability and evolutionary analyses of the coat protein gene of Tomato mosaic virus. Virus Genes 43:435-438.

44. Roossinck, M. J. 2010. Lifestyles of plant viruses. Philos. Trans. R. Soc. B 365:1899-1905.

45. Rubio, L., Abou-Jawdah, Y., Lin, H. X., and Falk, B. W. 2001. Geographically distant isolates of the crinivirus Cucurbit yellow stunting disorder virus show very low genetic diversity in the coat protein gene. J. Gen. Virol. 82:929-933.

46. Rubio, L., Ayllón, M. A., Kong, P., Fernández, A., Polek, M. L., Guerri, J., Moreno, P., and Falk, B. W. 2001. Genetic variation of Citrus tristeza virus isolates from California and Spain: Evidence for mixed infections and recombination. J. Virol. 75:8054-8062.

47. Stover, E., and Aradhya, M. 2005. Fig genetic resources and research at the US National Clonal Germplasm Repository in Davis, California. Acta Hortic. (ISHS) 798:57-68. http://www.actahort.org/books/798/798_6.htm

48. Tajima, F. 1989. Statistical method for testing the neutral mutation hypothesis by DNA polymorphism. Genetics 123:585-595.

49. Tamura, K., Peterson, D., Peterson, N., Stecher, G., Nei, M., and 
Kumar, S. 2011. MEGA5: Molecular evolutionary genetics analysis using maximum likelihood, evolutionary distance, and maximum parsimony methods. Mol. Biol. Evol. 28:2731-2739.

50. Tentchev, D., Verdin, E., Marchal, C., Jacquet, M., Aguilar, J. M., and Moury, B. 2011. Evolution and structure of Tomato spotted wilt virus populations: Evidence of extensive reassortment and insights into emergence processes. J. Gen. Virol. 92:961-973.

51. Vives, M. C., Rubio, L., Galipienso, L., Navarro, L., Moreno, P., and
Guerri, J. 2002. Low genetic variation between isolates of Citrus leaf blotch virus from different host species and of different geographical origins. J. Gen. Virol. 83:2587-2591.

52. Walia, J. J., Salem, N. M., and Falk, B. W. 2009. Partial sequence and survey analysis identify a multipartite, negative-sense RNA virus associated with fig mosaic. Plant Dis. 93:4-10.

53. Weir, B. S., and Cockerham, C. C. 1984. Estimating F-statistics for the analysis of population structure. Evolution 38:1358-1370. 